\title{
VALIDATION OF WATER PURIFICATION SYSTEM
}

\author{
NATARAJ HM, VISHAL GUPTA N*, RAVI G \\ Department of Pharmaceutics, JSS College of Pharmacy, Jagadguru Sri Shivarathreeswara University, JSS Medical Institutions Campus, \\ Mysuru, Karnataka, India. Email: vkguptajss@gmail.com
}

Received: 06 January 2017, Revised and Accepted: 21 January 2017

\section{ABSTRACT}

Objective: Validation of water treatment systems is required to achieve water with all preferred quality attributes. This also delivers a circumstantial to establish a total control over the process which screens efficacy, safety, and ultimately, the process outcomes. The goal of steering validation is to establish that a process when operated within established limits, yields a product of reliable and definite quality with a high degree of assurance.

Methods: The current work is an effort to deliberate several aspects of validation comprising different approaches, machineries of water purification systems, equipment qualifications, performance testing phases, microbial and chemical analysis of water samples, documentation, and post-validation monitoring. Mainly the validation is done for new water plants in pharmaceutical industry.

Results and Discussion: Sampling of water was carried out after each step in the purification process, and the results were found within limits.

Conclusion: Water purification systems must be operated in the interior regulatory guidelines as with pharmaceutical manufacture facilities. Successful achievement of validation is confirmed by various testing phases. Usually, a three-phase testing approach is recommended over an extended period to prove reliability and robustness of the system for producing water of specified quality with a high degree of assurance.

Keywords: Validation, Water purification systems, Quality attributes, Pharmaceutical manufacture facilities, Microbial and chemical analysis.

(C) 2017 The Authors. Published by Innovare Academic Sciences Pvt Ltd. This is an open access article under the CC BY license (http://creativecommons. org/licenses/by/4. 0/) DOI: http://dx.doi.org/10.22159/ajpcr.2017.v10i4.16955

\section{INTRODUCTION}

- High-quality water is needed for the manufacturing of pharmaceuticals. Water is the most regularly used raw material in pharmaceutical manufacturing.

- Water is directly or indirectly used in the pharmaceutical manufacturing such as a major part in injectable products and in cleaning of manufacturing equipment.

- It is one of the raw materials that are regularly treated by the pharmaceutical manufacturer previous to use because it cannot be provided by the vendor. Water is, therefore, an important raw material in good manufacturing practices (GMP) and in validating the manufacturing process

\section{Why purification?}

Although tap water is sensibly pure, it is always variable due to seasonal or regional variation in quality.

- To remove impurities and avoid microbial contamination of products.

- Pretreatment is contingent on quality of feed water.

Water is referred as "the elixir of life" - this term is most suitable to the pharmaceutical industry for which the quality of water is precarious and a high importance. It is an essential component of various pharmaceutical preparations and is also used to clean process equipment and in future, plays an essential role in pharmaceutical processing's [1].

It is, thus, significant that water should meet set values given in different official texts; moreover, the water purification system frequently delivers the definite quantity and quality of water so as to confirm that there is no contamination of the equipment or product. Several grades of this raw material (i.e., water) are described by United States Pharmacopoeia (USP), based on several quality parameters such as microbiological values, presence of contaminants including endotoxins, conductivity, nitrates, heavy metals, and total organic carbon (TOC). Water must be constantly tested and must comply with well-defined quality attributes [2].
From the last few years, in the pharmaceutical industry, there has been a rigorous focus on validation methodologies. Its real importance within a productive course is recognized in relative to a product's quality attributes such as safety, purity, and effectiveness. Guidelines pertaining to the general principles of process validation and has also defined process validation is published by the Food and Drug Administration (FDA) "as an established documented evidence which delivers a high degree of assurance that a specific process will reliably produce a product meeting its predetermined specifications and quality characteristics" [3].

The term, validation, is used to cover the entire field of current GMP, and thus, it is also a section of the quality assurance program. Validation is legible through the established documentation and it assurances a manufacturing process with assured product quality and similarity.

To obtain water with all the desired quality characteristics, validation of water purification systems is mandatory [4]. Production, storage of pharmaceutical water, and conveyance system must be validated because end-product testing alone is insufficient indication to confirm with a high degree of assurance that the system operates as it is purported, water treatment systems, which are highly dynamic in nature, must be validated, monitored closely and controlled to cater for the ever escalating quality needs of the pharmaceutical industry. This article is intended to discuss the consistency effectiveness and reproducibility of a water purification system along with its validation aspects.

\section{METHODS [5-7]}

A. Raw water: Well water supplied by municipalities with preliminary treatments like filtration and chlorination.

B. Water softening: In this mechanism, the calcium and magnesium ions are exchanged for sodium ions in a resin column. Softening equipment consideration includes: 


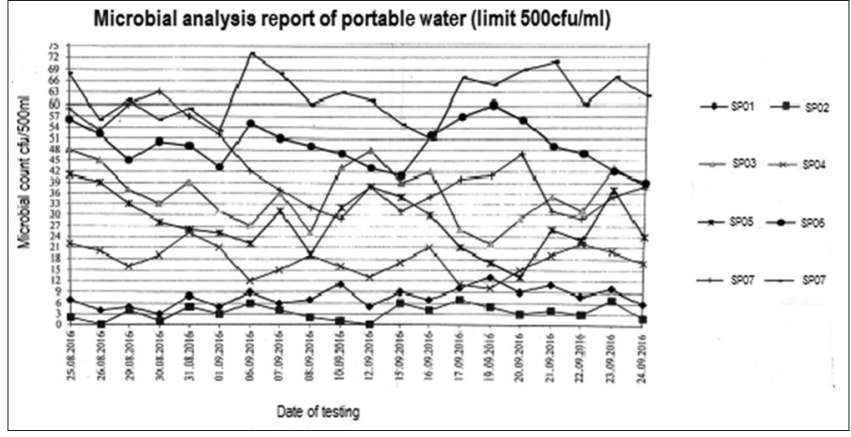

Fig. 1: Microbial analysis report of portable water

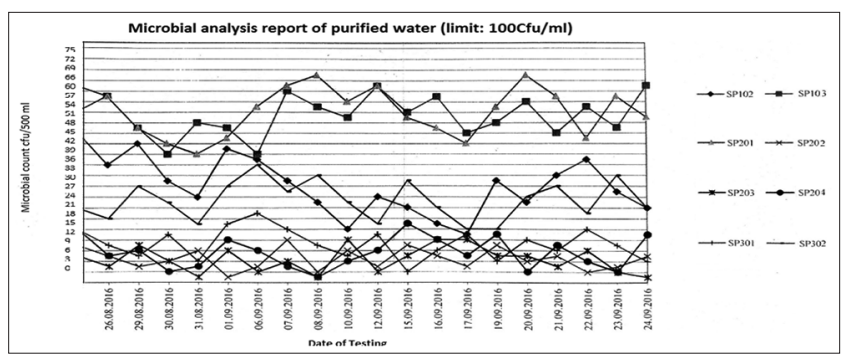

Fig. 2: Microbial analysis report of purified water

1. Regeneration frequency.

2. Requirement to sanitize the bed.

3. Replacement of resin.

4. Monitoring pressure drop and hardness.

C. Activated carbon: Used to remove chlorine and other organic materials from the water. The consideration includes:

1. Backwash frequency.

2. Continuous recirculation

3. Requirements to sanitize beds.

4. Replacement of carbon.

5. Monitoring pressure drops.

D. Filtration: It can be divided into three main classifications

1. Pre-filtration to remove large particulates.

2. Micro filters or bacteria retentive filters $(0.22 \mu$ size $)$.

3. Ultrafilters (range from 0.001 to $0.01 \mu \mathrm{m}$ ) the consideration includes:

- Porosity of membranes,

- Integrity testing of membranes (cartridge),

- Integrity testing of membrane to housing seal,

- Pressure drop across membrane,

- Microbial build up in filter assembly,

- Method of sanitizing assembly,

- Removal of sanitizing chemical residue,

- Particulate shedding of filter membrane.

E. Ion exchange: It is used to remove dissolved ionic impurities. Consideration includes:

1. Measuring quality and condition at various stages through the DI train, e.g., influent, post caution, post-anion, post mixed, etc,

2. Varying conditions during the service cycles,

3. Microbial conditions of bed,

4. Possible continuous recycling of water through the resin bed,

5. Quality of regenerated chemical- $\mathrm{H}_{2} \mathrm{SO}_{4}, \mathrm{HCL}, \mathrm{NaOH}$,

6. Condition and quality of air used for air blow on mixed bed units,

7. Dissolved and colloidal silica not detected by conductivity,

8. Amines from resins new and old

9. Sanitization and regeneration,

10. Frequency of regeneration and bed size,

11. $\mathrm{pH}$ adjustment to meet USP requirements,

12. $\mathrm{pH}$ measurement problems [8].

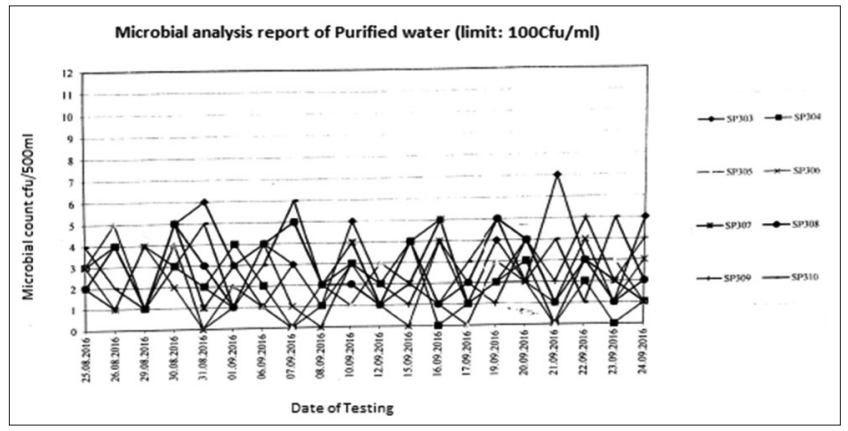

Fig. 3: Microbial analysis report of purified water

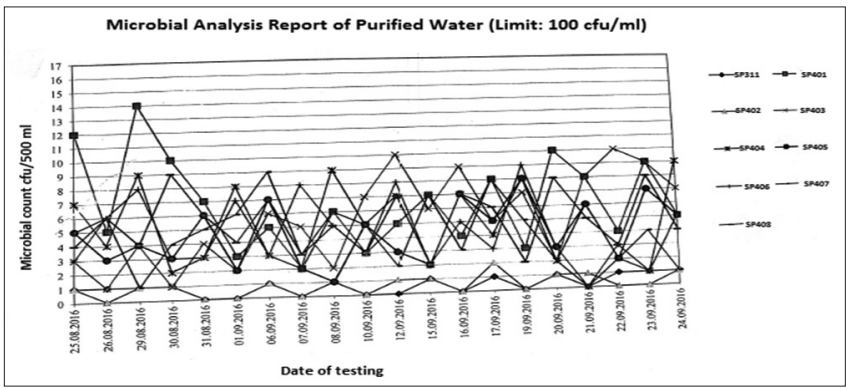

Fig. 4: Microbial analysis report of purified water

F. Reverse osmosis (RO): R0 treatment will remove a large portion of salt and particulates, bacteria, and pyrogenic materials. Considerations include:

1. Integrity test chemical and bacterial logical rejection,

2. Multiple modules,

3. Temperature dependent flow rate,

4. Sanitization and flushing residuals time to flush,

5. Replacement programs for modules,

6. Monitoring flow, pressures, temperature, $\mathrm{Cl}_{2}, \mathrm{pH}$, reject rates and conductivity.

G. Ultrafiltration: It is differ to RO with respect to membrane porosity. The consideration is similar to RO.

H. Distillation:

1. Single effect thermal distillation

2. Multiple effect thermal distillation,

3. Vapor compression distillation.

I. Ultraviolet radiation: Validity of this method for pharmaceutical water usage is not validated.

J. Heat: The heating and storing of water at $80^{\circ} \mathrm{C}$ has been shown effective to control the microbial quality.

\section{Equipment validation}

Design considerations

Design considerations comprise general information regarding several components or parts of water purification systems. The systems should be constructed using modular, off-the-shelf purification components to control cost and maximize validation efficiency, which finally fulfills pharmacopeia requirements [7]. These considerations must be designed correctly to prevent microbial growth. Materials of construction must be designated sensibly. The various parts of water purification systems should be validated.

\section{Water treatment piping}

- The piping of pre-treatment shall be done with SS304 and high pressure chrlorinated polyvinyl chrloride (CPVC) pipe and fittings. Fabrication of SS304 pipeline shall be done by argon welding and fabrication of CPVC pipeline shall be done solvent or threaded fittings. 
- The post-treatment piping shall be done with SS316L Tubes and fittings. Fabrication shall be done by using argon gas, to give crevice free welds.

- Care shall be taken that there is slope of minute 1:100 and dead leg as per 3D rule in the fabricated post-treatment system.

- The pre and post-treatment system and piping shall be compatible for heat sanitation and chemical cleaning.

\section{System design and overview}

Functional description

The PW generation system consists of raw water tank (client scope), sodium hypochlorite dosing system, raw water pump, sand filter, softener soft water storage tank, UF feed pump, UF fast flush pump, $10 \mu$ micron cartridge filter, UF membrane, UF and RO CIP system, antiscalent dosing system, sodium meta Bi-sulphite dosing system, ORP transmitter with dump valve, RO-I feed tank, RO-I water storage tank, RO-I feed water storage tank, RO-I feed pumps, $5 \mu$ micron cartridge filter, RO-I high pressure pump, RO system I, pH correction dosing system, RO-II feed tank, RO-II feed pump, $1 \mu$ micron cartridge filter, RO II high pressure pump, RO system II, electrodeionization unit and ultraviolet disinfectant, isolation valves and instruments [9]

The purified water is generated by dosing sodium hypochlorite, filtering through sand filter softening through softener to reduce the hardness, reducing microbial load and SDI below $<1$ through ultrafiltration unit, neutralizing the chlorine through sodium meta Bi-sulphate dosing, then dosing antiscalant for prevent scaling to RO membrane, then storing in RO-I feed tank, then feeding water to RO-I system for removal of total dissolved solids through 10 micron cartridge filter, then RO-I permeate water in RO-I storage tank, then this RO-I permeate water stored in an RO-I water storage tank and it is transferred through the RO-I water transfer pump to the RO-I

Table 1: Treated water quality standards

\begin{tabular}{|c|c|}
\hline Parameters & Limit \\
\hline $\mathrm{pH}$ & $5.5-7.0$ \\
\hline Conductivity (purified water) & $<1.25 \mu \mathrm{S} / \mathrm{cm} @ 25^{\circ} \mathrm{C}$ \\
\hline TOC & $<500 \mathrm{ppb}$ \\
\hline TVC & $<100 \mathrm{cfu} / \mathrm{ml}$ \\
\hline
\end{tabular}

TOC: Total organic carbon

Table 2: Design flow rates

\begin{tabular}{ll}
\hline Particulars & Flow $\left(\mathbf{m}^{3} / \mathbf{h r}\right)$ \\
\hline Multi grade filter & 12 \\
Softener & 12 \\
Ultra filtration system & 11 \\
Reverse osmosis system-I & 8.0 \\
Reverse osmosis system-II & 2.2 \\
EDI & 2.0
\end{tabular}

EDI: Electrodeionization water storage tank which is located on terrace. From there the water transferred to other utilities and also stored in RO-II Jacketed feed tank through gravity, then correcting $\mathrm{pH}$ by dosing sodium hydroxide, then feeding water to RO-II system for removal of remaining total dissolved solids through 5 Micron cartridge filter, then final polishing of the water is done by electro deionization system and finally disinfecting bacteria by ultraviolet disinfectant system. Then it stored in $2.5 \mathrm{KL}$ PW storage tank [10]. Treated water quality standards are shown in Table1.

The PW generation system designed for continuous generation of purified water, if there is no requirement of water RO system and electrodeionization unit, will be in standby mode and auto flushing will be programmed for every specific time. System sanitization has to be done during restarting and fouling of the system [11]. Design flow rates are shown in figure 2 .

This generation system is controlled by centralized control panel; critical parameters, viz., Tank levels, ORP, $\mathrm{pH}$, flow conductivity's shall be continuously monitored and controlled.

\section{Installation qualification (IQ)}

IQ ensures and proves that the system has been supplied and installed correctly and meets the predetermined specifications of the users. It usually involves the generation of an IQ protocol, a test and inspection plan for the system. All installation parameters should be documented and certified before operational qualification of the system. For an IQ of water treatment system following are typical key elements:

- Utilities requiring certifications includes electricity, compressed air, steam and feed water. Each must be checked properly at the time of installation of equipment for water treatment systems.

- Calibration of all method controlling instruments according to written procedures and certification that they meet the indicated tolerance limits for accuracy, precision, and also in terms of selectivity or specificity.

- Verify documentation on system design specifications comprising materials data and calibration certificates [12-14].

\section{Operation qualification $(0 Q)$}

The purpose of $\mathrm{OQ}$ is to launch, through documented testing, that all critical components are accomplished of operating within established limits and tolerances.

- It is the functional testing of system components are critical components.

- The purpose of $O Q$ is to confirm and document that the water supply system provides acceptable operational control under "at-rest" conditions [12-14].

\section{OQ checks}

- Capability to provide water of adequate quantity and quality to ensure accomplishment of specifications

- Capability to preserve general parameters such as pressure, temperature, flow at set points.

- Capability to maintain any critical parameters (Microbial level,

Table 3: Quality of treated water at different stages

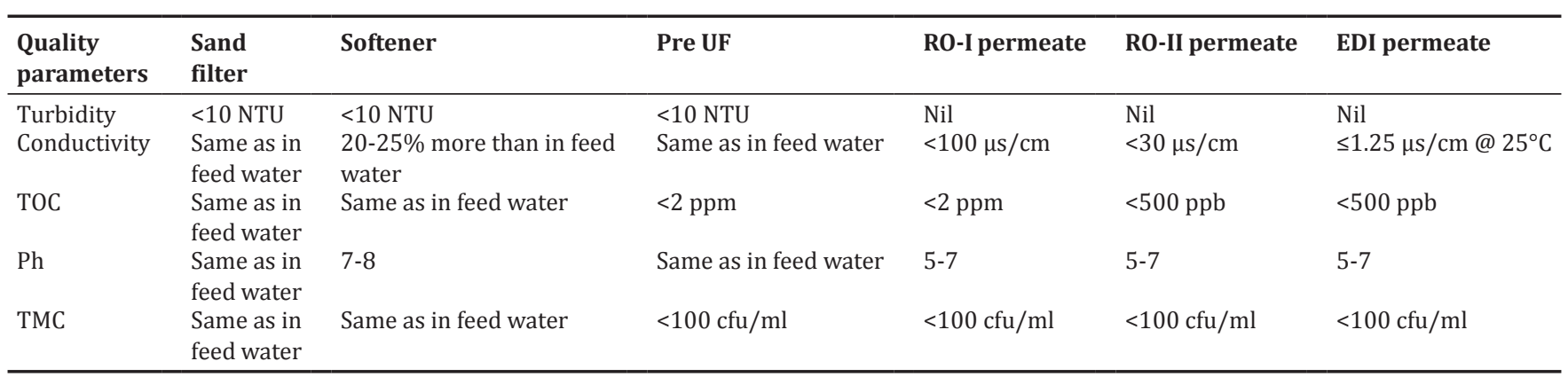

TOC: Total organic carbon, EDI: Electrodeionization, TMC: Total microbial count 
endotoxin, TOC, conductivity, pH, etc.) [15]

\section{Performance qualification (PQ)}

- The obstinacy of PQ is to verify and document that water supply system provides acceptable control under "full operational" conditions.

- $\quad$ PQ must follow successful completion of IQ and OQ.

- $\quad$ PQ verifies that completed time, critical parameters, as defined in the DQ are being achieved.

\section{According to the FDA's advice}

"The observed variability of the equipment between and within runs used as a basis for defining the total number of trials selected for the subsequent PQ studies of the process."

- $\quad P Q$ is used to demonstrate consistent achievement of critical parameters over time (such as $\mathrm{pH}, \mathrm{TOC}$, conductivity)

- $\quad$ PQ and OQ tests are sometimes performed in conjunction with one another

\section{Qualification phases [16,17]}

Three phase methodology suggested according to WHO Technical Report Series 929 to prove reliability and robustness.

\section{Phase 1 (investigational phase)}

- A test period is up to 2-4 weeks - amount the system.

- System to work uninterruptedly without failure or performance deviation

- Chemical and microbiological testing must include in agreement with a well-defined plan.

- Sample is taken daily from

- Inward feed-water.

- After every step in the decontamination process

- Each point of use and specified sample points.

- Develop

- Proper operating ranges and finalize operating, cleaning, sanitizing, and maintenance processes.

Table 4: Chemical analysis

\begin{tabular}{lll}
\hline $\begin{array}{l}\text { Sampling } \\
\text { points }\end{array}$ & $\begin{array}{l}\text { Type of } \\
\text { water }\end{array}$ & Tests performed \\
\hline SP02-SP07 & $\begin{array}{l}\text { Portable } \\
\text { water }\end{array}$ & $\begin{array}{l}\text { pH } \\
\text { Total hardness (as calcium carbonate) } \\
\text { Chloride (as chlorine) }\end{array}$ \\
& & $\begin{array}{l}\text { Dissolved solids } \\
\text { Description } \\
\text { pH }\end{array}$ \\
& Peavy metals \\
& water & Nitrates \\
& & $\begin{array}{l}\text { Aluminium } \\
\text { Conductivity } \\
\text { Bacterial Endotoxins }\end{array}$ \\
& & \\
\end{tabular}

- Demonstrate delivery of water and production of the required quality and quantity

- Use and define the standard operating procedures (SOPs) for operation, maintenance, troubleshooting, and sanitization.

- Measure provisional alert and action levels.

- Develop and define test-failure process.

Phase 2 (verification step)

- A further test period of 2-4 weeks - additional intensive checking of the system.

- Utilization of all the SOPs after completion of phase 1.

- Sampling scheme normally the same as in phase 1.

- Water can be utilized for manufacturing purposes during this phase.

\section{Phase-2 demonstrates}

- Dependable operation within recognized ranges. Hence, it demonstrates that the system is in control.

- Consistent production and delivery of water of the required amount and quality when the system is operated according with the SOPs.

Phase 3 (verifying long-term control)

- $\quad$ Over 1 year after the acceptable completion of phase 2 .

- Water can be utilized for manufacturing purposes during this phase.

- Demonstrate: Extended consistent performance, that seasonal variations are evaluated, sample locations, sampling frequencies and tests should be reduced to the normal routine pattern based on well-known procedures proven during phases 1 and 2 .

Monitoring

- Monitoring and feedback data are significant in maintaining the performance systems.

- Parameters include.

- Conductivity, TOC, flow, pressure, temperature,

- Samples taken from points of use and definite sample points,

- Tests must include chemical, physical and microbial attributes,

- For example, stable state can be achieved by applying automatic continuous checking of TOC and conductivity of the water system. They are the major quality attributes of water by which organic and inorganic impurities can be determined.

\section{Maintenance}

A controlled, documented maintenance covers:

- Definite frequency with plan and instructions,

- Calibration program, SOPs for tasks, record and review of complications and faults during maintenance,

- System sanitization and bioburden control, systems in place to control multiplying of microbes and Techniques for sanitizing or sterilization,

- Consider during design stage - then validated,

- Precautions if water not kept in the range of $70-80^{\circ} \mathrm{C}$.

Revalidation and change control

- A laboratory applying a definite method should confirm that they

Table 5: Sampling point: SP02 (After NaOCl dosing)

\begin{tabular}{|c|c|c|c|c|c|c|c|c|c|c|c|}
\hline \multirow[t]{2}{*}{ Test } & \multirow[t]{2}{*}{ Specification } & \multicolumn{10}{|c|}{ Date of sampling and results } \\
\hline & & $25 / 8 / 16$ & $26 / 8 / 16$ & $29 / 8 / 16$ & $30 / 8 / 16$ & $31 / 8 / 16$ & $01 / 9 / 16$ & $06 / 9 / 16$ & $07 / 9 / 16$ & $08 / 9 / 16$ & $10 / 9 / 16$ \\
\hline Description & $\begin{array}{l}\text { A clear, colourless } \\
\text { and tasteless } \\
\text { liquid }\end{array}$ & A clear, col & ourless and & d tasteless l & liquid & & & & & & \\
\hline $\mathrm{pH}$ & $6.5-8.5$ & 6.88 & 6.89 & 6.98 & 7.01 & 7.04 & 6.99 & 6.87 & 6.88 & 6.91 & 6.97 \\
\hline $\begin{array}{l}\text { Total hardness (as } \\
\text { calcium carbonate) }\end{array}$ & NMT 600 mg/l & 52 & 57 & 53 & 47 & 56 & 58 & 55 & 61 & 58 & 59 \\
\hline $\begin{array}{l}\text { Chloride (as } \\
\text { chlorine) }\end{array}$ & NMT 1000 mg/l & 547 & 587 & 548 & 598 & 614 & 574 & 542 & 564 & 542 & 528 \\
\hline Dissolved solids & NMT 2000 mg/l & 624 & 604 & 574 & 582 & 564 & 555 & 594 & 542 & 554 & 528 \\
\hline
\end{tabular}


have documentary evidence that the method has been appropriately validated. "The accountability is with the user to ensure that the validation documented in the method is sufficiently complete to meet his or her needs" [18]

- Once the validation is completed, the SOPs are formalized

- $\quad$ Routine operation should be performed according to the established SOP.

- If any deviation from SOP observed, regulate the change and their impact on whole system.
- Revalidation and assessment should be performed depending upon the impact of the change on system.

\section{RESULTS AND DISCUSSIONS}

Sampling of water was carried out after each step in the purification process.

- $\quad$ Sampling point: SP02 (After NaOCl Dosing) results are shown in table 4.

- Multigrade filter deals a highly efficient removal of suspended fragmented matter from the water. So by this process, foreign particles are removed

Table 6: Sampling point: SP04 (after multi grade filter)

\begin{tabular}{|c|c|c|c|c|c|c|c|c|c|c|c|}
\hline \multirow[t]{2}{*}{ Test } & \multirow[t]{2}{*}{ Specification } & \multicolumn{10}{|c|}{ Date of sampling and results } \\
\hline & & $25 / 8 / 16$ & $26 / 8 / 16$ & $29 / 8 / 16$ & $30 / 8 / 16$ & $31 / 8 / 16$ & $01 / 9 / 16$ & $06 / 9 / 16$ & $07 / 9 / 16$ & $08 / 9 / 16$ & $10 / 9 / 16$ \\
\hline Description & $\begin{array}{l}\text { A clear, colourless } \\
\text { and tasteless } \\
\text { liquid }\end{array}$ & \multicolumn{10}{|c|}{ A clear, colourless and tasteless liquid } \\
\hline $\mathrm{pH}$ & $6.5-8.5$ & 7.04 & 6.85 & 7.45 & 7.65 & 7.94 & 7.1 & 6.89 & 6.92 & 6.99 & 7.98 \\
\hline $\begin{array}{l}\text { Total hardness (as } \\
\text { calcium carbonate) }\end{array}$ & NMT 600 mg/l & 47 & 48 & 52 & 56 & 58 & 54 & 62 & 65 & 64 & 58 \\
\hline Chloride (as chlorine) & NMT 1000 mg/l & 438 & 485 & 468 & 446 & 428 & 439 & 478 & 469 & 476 & 488 \\
\hline Dissolved solids & NMT 2000 mg/l & 576 & 568 & 535 & 564 & 546 & 588 & 539 & 574 & 589 & 569 \\
\hline
\end{tabular}

Table 7: Sampling point: SP07 (after softner)

\begin{tabular}{|c|c|c|c|c|c|c|c|c|c|c|c|}
\hline \multirow[t]{2}{*}{ Test } & \multirow[t]{2}{*}{ Specification } & \multicolumn{10}{|c|}{ Date of sampling and results } \\
\hline & & $25 / 8 / 16$ & 26/8/16 & $29 / 8 / 16$ & $30 / 8 / 16$ & $31 / 8 / 16$ & $01 / 9 / 16$ & $06 / 9 / 16$ & $07 / 9 / 16$ & $08 / 9 / 16$ & $10 / 9 / 16$ \\
\hline Description & $\begin{array}{l}\text { A clear, colourless } \\
\text { and tasteless } \\
\text { liquid }\end{array}$ & A clear, co & lourless an & Id tasteless & liquid & & & & & & \\
\hline $\mathrm{pH}$ & $6.5-8.5$ & 6.54 & 6.24 & 6.56 & 6.48 & 6.48 & 6.44 & 6.12 & 7.14 & 6.34 & 6.14 \\
\hline $\begin{array}{l}\text { Total hardness (as } \\
\text { calcium carbonate) }\end{array}$ & NMT 600 mg/l & Nil & Nil & Nil & Nil & Nil & Nil & Nil & Nil & Nil & Nil \\
\hline Chloride (as chlorine) & NMT 1000 mg/l & Nil & Nil & Nil & Nil & Nil & Nil & Nil & Nil & Nil & Nil \\
\hline Dissolved solids & NMT $2000 \mathrm{mg} / \mathrm{l}$ & 287 & 297 & 248 & 276 & 298 & 323 & 302 & 278 & 267 & 283 \\
\hline
\end{tabular}

Table 8: Sampling point: SP102 (after ultra-filtration)

\begin{tabular}{|c|c|c|c|c|c|c|c|c|c|c|c|}
\hline \multirow[t]{2}{*}{ Test } & \multirow[t]{2}{*}{ Specification } & \multicolumn{10}{|c|}{ Date of sampling and results } \\
\hline & & $25 / 8 / 16$ & $26 / 8 / 16$ & $29 / 8 / 16$ & $30 / 8 / 16$ & $31 / 8 / 16$ & $01 / 9 / 16$ & $06 / 9 / 16$ & $07 / 9 / 16$ & $08 / 9 / 16$ & $10 / 9 / 16$ \\
\hline Description & $\begin{array}{l}\text { A clear, colourless } \\
\text { and tasteless liquid }\end{array}$ & \multicolumn{10}{|c|}{ A clear, colourless and tasteless liquid } \\
\hline $\mathrm{pH}$ & $5.0-7.0$ & 6.99 & 6.87 & 6.88 & 6.91 & 6.97 & 6.88 & 6.89 & 6.98 & 7.01 & 7.04 \\
\hline Heavy metals & NMT $0.1 \mathrm{ppm}$ & $<0.1$ & $<0.1$ & $<0.1$ & $<0.1$ & $<0.1$ & $<0.1$ & $<0.1$ & $<0.1$ & $<0.1$ & $<0.1$ \\
\hline Nitrates & NMT $0.2 \mathrm{ppm}$ & $<0.2$ & $<0.2$ & $<0.2$ & $<0.2$ & $<0.2$ & $<0.2$ & $<0.2$ & $<0.2$ & $<0.2$ & $<0.2$ \\
\hline Aluminium & NMT 10 ppb & $<10$ & $<10$ & $<10$ & $<10$ & $<10$ & $<10$ & $<10$ & $<10$ & $<10$ & $<10$ \\
\hline Conductivity & NMT $5.1 \mu \mathrm{S} / \mathrm{cm}$ & 3.2 & 3.0 & 3.4 & 2.9 & 2.7 & 3.2 & 3.1 & 2.9 & 2.8 & 3.1 \\
\hline $\begin{array}{l}\text { Bacterial } \\
\text { Endotoxins }\end{array}$ & NMT $0.2 \mathrm{EU} / \mathrm{mg}$ & $<0.2$ & $<0.2$ & $<0.2$ & $<0.2$ & $<0.2$ & $<0.2$ & $<0.2$ & $<0.2$ & $<0.2$ & $<0.2$ \\
\hline
\end{tabular}

Table 9: Sampling point: SP201 (after $10 \mu$ filter)

\begin{tabular}{|c|c|c|c|c|c|c|c|c|c|c|c|}
\hline \multirow[t]{2}{*}{ Test } & \multirow[t]{2}{*}{ Specification } & \multicolumn{10}{|c|}{ Date of sampling and results } \\
\hline & & $25 / 8 / 16$ & $26 / 8 / 16$ & $29 / 8 / 16$ & $30 / 8 / 16$ & $31 / 8 / 16$ & $01 / 9 / 16$ & $06 / 9 / 16$ & $07 / 9 / 16$ & $08 / 9 / 16$ & $10 / 9 / 16$ \\
\hline Description & $\begin{array}{l}\text { A clear, colourless } \\
\text { and tasteless liquid }\end{array}$ & \multicolumn{10}{|c|}{ A clear, colourless and tasteless liquid } \\
\hline $\mathrm{pH}$ & 5.0 to 7.0 & 5.32 & 5.41 & 5.42 & 5.31 & 5.48 & 4.85 & 5.39 & 5.94 & 4.91 & 5.13 \\
\hline Heavy metals & NMT $0.1 \mathrm{ppm}$ & $<0.1$ & $<0.1$ & $<0.1$ & $<0.1$ & $<0.1$ & $<0.1$ & $<0.1$ & $<0.1$ & $<0.1$ & $<0.1$ \\
\hline Nitrates & NMT $0.2 \mathrm{ppm}$ & $<0.2$ & $<0.2$ & $<0.2$ & $<0.2$ & $<0.2$ & $<0.2$ & $<0.2$ & $<0.2$ & $<0.2$ & $<0.2$ \\
\hline Aluminium & NMT $10 \mathrm{ppb}$ & $<10$ & $<10$ & $<10$ & $<10$ & $<10$ & $<10$ & $<10$ & $<10$ & $<10$ & $<10$ \\
\hline Conductivity & $\mathrm{NMT} 5.1 \mu \mathrm{S} / \mathrm{cm}$ & 2.3 & 2.8 & 2.5 & 2.1 & 2.9 & 2.7 & 3.2 & 3.1 & 2.6 & 2.4 \\
\hline $\begin{array}{l}\text { Bacterial } \\
\text { endotoxins }\end{array}$ & NMT $0.2 \mathrm{EU} / \mathrm{mg}$ & $<0.2$ & $<0.2$ & $<0.2$ & $<0.2$ & $<0.2$ & $<0.2$ & $<0.2$ & $<0.2$ & $<0.2$ & $<0.2$ \\
\hline
\end{tabular}


from the water; the results are shown in Table 6 (Sampling point: SP04).

- Water softeners of an alternated sodium resin which can remove hard minerals from the water; the results are shown in Table 7 (Sampling point: SP07).

- Sampling point: SP102 (After Ultra filtration) results are shown in Table 8.

- $\quad$ Sampling point: SP201 (After $10 \mu$ Filter) results are shown in Table 9.

- RO is the finest filtration open, RO removes $90-99 \%$ of particles, bacteria, pyrogens, colloids, dissolved organic, and inorganic substances $>200$-300 molecular weight range or larger than the membrane's pore size of 150-200 angstroms; the results are shown in Table 10 (Sampling point: SP204).

- $\quad$ Sampling point: SP302 (After pH Correction) results are shown in Table 11.

- Sampling point: SP306 (After Reverse Osmosis-2) results are shown in Table 12.

- $\quad$ Electron deionization column which removes dissolved minerals and salts, and some dissolved organic matter, from the water stream crossing ion exchange resins, the results are shown in Table 13 (Sampling point: SP309).

- Ultraviolet light $(\lambda=254 \mathrm{~nm})$ is used in the final step in the treatment for the purpose of avoiding the growth of microorganisms, and reducing TOC. The results are shown in Table 14 (Sampling point: SP311).

- Sampling point: SP401 (PW Storage tank). The results are shown in Table 15

- TOC test is executed for water samples, results are within the acceptance limits $(<500 \mathrm{ppb})$

- Chemical and microbial analysis, we found that the results are complies with in the limits.

Table 10: Sampling point: SP204 (After reverse osmosis-1)

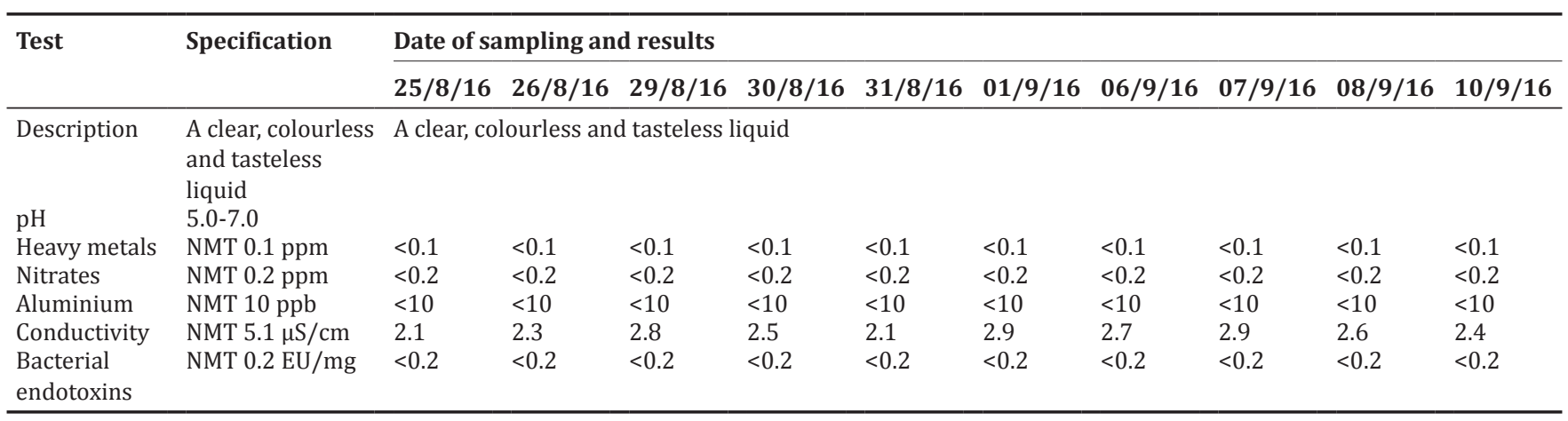

Table 11: Sampling point: SP302 (After pH Correction)

\begin{tabular}{|c|c|c|c|c|c|c|c|c|c|c|c|}
\hline \multirow[t]{2}{*}{ Test } & \multirow[t]{2}{*}{ Specification } & \multicolumn{10}{|c|}{ Date of sampling and results } \\
\hline & & $25 / 8 / 16$ & $26 / 8 / 16$ & $29 / 8 / 16$ & $30 / 8 / 16$ & $31 / 8 / 16$ & $01 / 9 / 16$ & $06 / 9 / 16$ & $07 / 9 / 16$ & $08 / 9 / 16$ & $10 / 9 / 16$ \\
\hline Description & $\begin{array}{l}\text { A clear, colourless } \\
\text { and tasteless } \\
\text { liquid }\end{array}$ & \multicolumn{10}{|c|}{ A clear, colourless and tasteless liquid } \\
\hline $\mathrm{pH}$ & $5.0-7.0$ & 6.45 & 6.35 & 6.45 & 6.94 & 6.45 & 6.37 & 6.15 & 6.48 & 6.24 & 6.27 \\
\hline Heavy metals & NMT 0.1 ppm & $<0.1$ & $<0.1$ & $<0.1$ & $<0.1$ & $<0.1$ & $<0.1$ & $<0.1$ & $<0.1$ & $<0.1$ & $<0.1$ \\
\hline Aluminium & NMT $10 \mathrm{ppb}$ & $<10$ & $<10$ & $<10$ & $<10$ & $<10$ & $<10$ & $<10$ & $<10$ & $<10$ & $<10$ \\
\hline Conductivity & NMT $5.1 \mu \mathrm{S} / \mathrm{cm}$ & 2.4 & 2.6 & 2.1 & 2.6 & 2.4 & 2.9 & 2.7 & 2.4 & 2.6 & 2.1 \\
\hline $\begin{array}{l}\text { Bacterial } \\
\text { endotoxins }\end{array}$ & NMT $0.2 \mathrm{EU} / \mathrm{mg}$ & $<0.2$ & $<0.2$ & $<0.2$ & $<0.2$ & $<0.2$ & $<0.2$ & $<0.2$ & $<0.2$ & $<0.2$ & $<0.2$ \\
\hline
\end{tabular}

Table 12: Sampling point: SP306 (After reverse osmosis-2)

\begin{tabular}{|c|c|c|c|c|c|c|c|c|c|c|c|}
\hline \multirow[t]{2}{*}{ Test } & \multirow[t]{2}{*}{ Specification } & \multicolumn{10}{|c|}{ Date of sampling and results } \\
\hline & & $25 / 8 / 16$ & $26 / 8 / 16$ & 29/8/16 & $30 / 8 / 16$ & $31 / 8 / 16$ & $01 / 9 / 16$ & $06 / 9 / 16$ & $07 / 9 / 16$ & $08 / 9 / 16$ & $10 / 9 / 16$ \\
\hline Description & $\begin{array}{l}\text { A clear, colourless } \\
\text { and tasteless } \\
\text { liquid }\end{array}$ & \multicolumn{10}{|c|}{ A clear, colourless and tasteless liquid } \\
\hline $\mathrm{pH}$ & $5.0-7.0$ & 6.23 & 6.41 & 6.84 & 6.48 & 6.29 & 6.46 & 6.29 & 6.58 & 6.49 & 6.44 \\
\hline Heavy metals & NMT $0.1 \mathrm{ppm}$ & $<0.1$ & $<0.1$ & $<0.1$ & $<0.1$ & $<0.1$ & $<0.1$ & $<0.1$ & $<0.1$ & $<0.1$ & $<0.1$ \\
\hline Aluminium & NMT 10 ppb & $<10$ & $<10$ & $<10$ & $<10$ & $<10$ & $<10$ & $<10$ & $<10$ & $<10$ & $<10$ \\
\hline Conductivity & NMT $5.1 \mu \mathrm{S} / \mathrm{cm}$ & 2.1 & 2.3 & 2.8 & 2.5 & 2.1 & 2.3 & 2.8 & 2.5 & 2.1 & 2.3 \\
\hline $\begin{array}{l}\text { Bacterial } \\
\text { endotoxins }\end{array}$ & NMT $0.2 \mathrm{EU} / \mathrm{mg}$ & $<0.2$ & $<0.2$ & $<0.2$ & $<0.2$ & $<0.2$ & $<0.2$ & $<0.2$ & $<0.2$ & $<0.2$ & $<0.2$ \\
\hline
\end{tabular}


Table 13: Sampling point: SP309 (After electron de-ionization system)

\begin{tabular}{|c|c|c|c|c|c|c|c|c|c|c|c|}
\hline \multirow[t]{2}{*}{ Test } & \multirow[t]{2}{*}{ Specification } & \multicolumn{10}{|c|}{ Date of sampling and results } \\
\hline & & $25 / 8 / 16$ & $26 / 8 / 16$ & $29 / 8 / 16$ & $30 / 8 / 16$ & $31 / 8 / 16$ & $01 / 9 / 16$ & $06 / 9 / 16$ & $07 / 9 / 16$ & $08 / 9 / 16$ & $10 / 9 / 16$ \\
\hline Description & $\begin{array}{l}\text { A clear, colourless } \\
\text { and tasteless } \\
\text { liquid }\end{array}$ & \multicolumn{10}{|c|}{ A clear, colourless and tasteless liquid } \\
\hline $\mathrm{pH}$ & $5.0-7.0$ & 6.44 & 6.12 & 7.14 & 6.34 & 6.14 & 6.54 & 6.24 & 6.56 & 6.48 & 6.48 \\
\hline Heavy metals & NMT 0.1 & $<0.1$ & $<0.1$ & $<0.1$ & $<0.1$ & $<0.1$ & $<0.1$ & $<0.1$ & $<0.1$ & $<0.1$ & $<0.1$ \\
\hline Nitrates & NMT $0.2 \mathrm{ppm}$ & $<0.2$ & $<0.2$ & $<0.2$ & $<0.2$ & $<0.2$ & $<0.2$ & $<0.2$ & $<0.2$ & $<0.2$ & $<0.2$ \\
\hline Aluminium & NMT 10 ppb & $<10$ & $<10$ & $<10$ & $<10$ & $<10$ & $<10$ & $<10$ & $<10$ & $<10$ & $<10$ \\
\hline Conductivity & NMT $5.1 \mu \mathrm{S} / \mathrm{cm}$ & 2.9 & 2.8 & 3.1 & 3.2 & 3.0 & 3.4 & 2.9 & 2.7 & 3.2 & 3.1 \\
\hline $\begin{array}{l}\text { Bacterial } \\
\text { endotoxins }\end{array}$ & NMT $0.2 \mathrm{EU} / \mathrm{mg}$ & $<0.2$ & $<0.2$ & $<0.2$ & $<0.2$ & $<0.2$ & $<0.2$ & $<0.2$ & $<0.2$ & $<0.2$ & $<0.2$ \\
\hline
\end{tabular}

Table 14: Sampling point: SP311 (After UV)

\begin{tabular}{|c|c|c|c|c|c|c|c|c|c|c|c|}
\hline \multirow[t]{2}{*}{ Test } & \multirow[t]{2}{*}{ Specification } & \multicolumn{10}{|c|}{ Date of sampling and results } \\
\hline & & $25 / 8 / 16$ & $26 / 8 / 16$ & 29/8/16 & $30 / 8 / 16$ & $31 / 8 / 16$ & $01 / 9 / 16$ & $06 / 9 / 16$ & $07 / 9 / 16$ & $08 / 9 / 16$ & $10 / 9 / 16$ \\
\hline Description & $\begin{array}{l}\text { A clear, colourless } \\
\text { and tasteless } \\
\text { liquid }\end{array}$ & \multicolumn{10}{|c|}{ A clear, colourless and tasteless liquid } \\
\hline $\mathrm{pH}$ & $5.0-7.0$ & 6.25 & 6.36 & 6.45 & 6.14 & 6.85 & 6.45 & 6.35 & 6.56 & 6.84 & 6.38 \\
\hline Heavy metals & NMT $0.1 \mathrm{ppm}$ & $<0.1$ & $<0.1$ & $<0.1$ & $<0.1$ & $<0.1$ & $<0.1$ & $<0.1$ & $<0.1$ & $<0.1$ & $<0.1$ \\
\hline Aluminium & NMT $10 \mathrm{ppb}$ & $<10$ & $<10$ & $<10$ & $<10$ & $<10$ & $<10$ & $<10$ & $<10$ & $<10$ & $<10$ \\
\hline Conductivity & NMT $5.1 \mu \mathrm{S} / \mathrm{cm}$ & 2.8 & 3.1 & 2.9 & 3.4 & 3.5 & 2.9 & 2.3 & 3.9 & 3.4 & 2.8 \\
\hline $\begin{array}{l}\text { Bacterial } \\
\text { endotoxins }\end{array}$ & NMT $0.2 \mathrm{EU} / \mathrm{mg}$ & $<0.2$ & $<0.2$ & $<0.2$ & $<0.2$ & $<0.2$ & $<0.2$ & $<0.2$ & $<0.2$ & $<0.2$ & $<0.2$ \\
\hline
\end{tabular}

Table 15: Sampling point: SP401 (PW Storage tank)

\begin{tabular}{|c|c|c|c|c|c|c|c|c|c|c|c|}
\hline \multirow[t]{2}{*}{ Test } & \multirow[t]{2}{*}{ Specification } & \multicolumn{10}{|c|}{ Date of sampling and results } \\
\hline & & $25 / 8 / 16$ & $26 / 8 / 16$ & $29 / 8 / 16$ & $30 / 8 / 16$ & $31 / 8 / 16$ & $01 / 9 / 16$ & $06 / 9 / 16$ & $07 / 9 / 16$ & $08 / 9 / 16$ & $10 / 9 / 16$ \\
\hline Description & $\begin{array}{l}\text { A clear, colourless } \\
\text { and tasteless } \\
\text { liquid }\end{array}$ & \multicolumn{10}{|c|}{ A clear, colourless and tasteless liquid } \\
\hline $\mathrm{pH}$ & $5.0-7.0$ & 6.12 & 6.24 & 6.07 & 6.45 & 5.98 & 6.41 & 6.22 & 6.31 & 6.11 & 6.04 \\
\hline Heavy metals & NMT $0.1 \mathrm{ppm}$ & $<0.1$ & $<0.1$ & $<0.1$ & $<0.1$ & $<0.1$ & $<0.1$ & $<0.1$ & $<0.1$ & $<0.1$ & $<0.1$ \\
\hline Aluminium & NMT $10 \mathrm{ppb}$ & $<10$ & $<10$ & $<10$ & $<10$ & $<10$ & $<10$ & $<10$ & $<10$ & $<10$ & $<10$ \\
\hline Conductivity & NMT $5.1 \mu \mathrm{S} / \mathrm{cm}$ & 2.4 & 2.6 & 2.1 & 2.3 & 2.8 & 2.5 & 2.6 & 2.4 & 2.9 & 2.7 \\
\hline $\begin{array}{l}\text { Bacterial } \\
\text { endotoxins }\end{array}$ & NMT $0.2 \mathrm{EU} / \mathrm{mg}$ & $<0.2$ & $<0.2$ & $<0.2$ & $<0.2$ & $<0.2$ & $<0.2$ & $<0.2$ & $<0.2$ & $<0.2$ & $<0.2$ \\
\hline
\end{tabular}

Table 16: Microbial analysis

\begin{tabular}{llll}
\hline $\begin{array}{l}\text { Sampling } \\
\text { points }\end{array}$ & Type of water & $\begin{array}{l}\text { Tests } \\
\text { performed }\end{array}$ & Microbial limit \\
\hline SP01-SP07 & Portable water & TMC & NMT $500 \mathrm{cfu} / \mathrm{ml}$ \\
SP102-SP408 & Purified water & TMC & NMT 100 cfu/ml \\
\hline
\end{tabular}

TMC: Total microbial count

\section{Microbial analysis reports}

- Microbial analysis report of portable water, purified water results are shown in figure no 1-4 and table 16

\section{CONCLUSION}

Water treatment systems need be operated within regulatory guidelines as with pharmaceutical production facilities. To validate these systems, there should be documented evidence that the system is operating constantly and allowing to the desired specifications. Validation is a tool for total quality management and it is necessary for process optimisation, efficacy, safety, and assurance of quality. Such validation protocols fulfill regulatory requirements and deliver good business sense. Successful execution of validation is ensured by various testing phases. A three-phase testing approach is suggested over an extended period to prove robustness and reliability of the system for producing water of specified quality with a high degree of assurance.

\section{REFERENCES}

1. Hultqvist A. Practical guidelines for qualifying purified water systems. Pharm Technol Europe 2007;19(12). Available from: http://www. ptemag.com/pharmte cheurope/Validation/ArticleStandard/Article/de tail/480191. [Last accessed on 2009 May 24]

2. The United States Pharmacopoeia. USP XXII/The National Formulary NF XVII. Rockville: United States Pharmacopeial Convention; 1990.

3. Food and Drug Administration. Guideline on General Principles of Process Validation. Rockville, MD: FDA; 1984.

4. PMA Deionized Water Committee. Validation and control concepts for water treatment systems. Pharm Technol 1985;9(11):50-6.

5. Potdar MA. Pharmaceutical Quality Assurance. Geneva: World Health Organisation; 2007. p. 8.84-8.94.

6. McBride D, Mukhopadhyay D. Higher water recovery and solute rejection through a new RO process. Ultrapure Water 1997;14(5):24-9.

7. Paul DH. A review of membrane water treatment technologies. Ultrapure Water 1997;14(3):39-42. 
8. Debajit B, Yadav RN, Sangra A, Shahin L, Chaubey AK. Production, purification and characterization of nattokinase from bacillus subtilis, isolated from tea garden soil samples of Dibrugarh, Assam. Int J Pharm Pharm Sci 2012;5(3):124-5.

9. Singh R. A review of membrane technologies, reverse osmosis, nanofiltration and ultrafiltration. Ultrapure Water 1997;14(3):21-9.

10. Munson TE. FDA View on Water System Validation. Proceedings of the Pharmacy Technician Conference 10-12 September; 1985.

11. Nash RA. Validation of pharmaceutical processes. In: Swarbrick J, Boylan JC, editors. Encyclopedia of Pharmaceutical Technology. $2^{\text {nd }}$ ed. New York: Marcel Dekker; 2002. p. 2917-31. Pahwa R, Khatri S, Rathour A, Lamba HS. Validation of moist heat sterilization cycles. J Sci Pharm 2004;5(4):125-30.

12. Carlrton FJ, Agalloco JP. Validation of Pharmaceutical Process. New York: Marcel Dekker; 1986

13. Johnson WM. Validation of water systems for sterile and nonsterile products. In: Berry IR, Nash RA, editors. Pharmaceutical Process Validation. $2^{\text {nd }}$ ed. New York: Marcel Dekker Inc., Revised and Expanded; 1993. p. 299-317.

14. Carleton FJ, Agalloco JP. Validation of Pharmaceutical Processes. $3^{\text {rd }}$ ed. New York: CRC Press; 2007. p. 59-92.

15. Available from: http://www.authorstream.com

16. Ferreira JA, Silva Z, Oliveira RC, Branquinho MR. Bacterial Contaminants in Water and Dialysate Used for Haemodialysis Therapy in Rio de Janeiro (1999-2001). XXI Congresso Brasileiro de Microbiologia (Brazilian Congress of Microbiology). 2001, IH 040. p. 148.

17. Palmieri MJ, Carito SL, Meyer RF. Comparison of rapid NFT and API $20 \mathrm{E}$ with conventional methods for identification of gram-negative nonfermentative bacilli from pharmaceuticals and cosmetics. Appl Environ Microbiol 1988;54:2838-41.

18. Ravichandran V, Shalini S, Sundram KM, Rajak H. Validation of analytical methods - Strategies \& importance. Int J Pharm Pharm Sci 2010;2(3):18-22. 